University of Nebraska - Lincoln

DigitalCommons@University of Nebraska - Lincoln

USGS Staff - Published Research

US Geological Survey

2-6-2007

\title{
The Art and Science of Weed Mapping
}

\author{
David T. Barnett \\ Colorado State University - Fort Collins \\ Thomas J. Stohlgren \\ National Institute of Invasive Species Science, Fort Collins Science Center \\ Catherine S. Jarnevich \\ National Institute of Invasive Species Science, Fort Collins Science Center \\ Geneva W. Chong \\ Northern Rocky Mountain Science Center, US Geological Survey \\ Jenny A. Ericson \\ National Invasive Species Program, National Wildlife Refuge System \\ See next page for additional authors
}

Follow this and additional works at: https://digitalcommons.unl.edu/usgsstaffpub

Part of the Earth Sciences Commons

Barnett, David T.; Stohlgren, Thomas J.; Jarnevich, Catherine S.; Chong, Geneva W.; Ericson, Jenny A.; Davern, Tracy R.; and Simonson, Sara E., "The Art and Science of Weed Mapping" (2007). USGS Staff -Published Research. 106.

https://digitalcommons.unl.edu/usgsstaffpub/106

This Article is brought to you for free and open access by the US Geological Survey at DigitalCommons@University of Nebraska - Lincoln. It has been accepted for inclusion in USGS Staff -- Published Research by an authorized administrator of DigitalCommons@University of Nebraska - Lincoln. 


\section{Authors}

David T. Barnett, Thomas J. Stohlgren, Catherine S. Jarnevich, Geneva W. Chong, Jenny A. Ericson, Tracy

R. Davern, and Sara E. Simonson 


\title{
The Art and Science of Weed Mapping
}

\author{
David T. Barnett • Thomas J. Stohlgren • \\ Catherine S. Jarnevich • Geneva W. Chong • \\ Jenny A. Ericson • Tracy R. Davern • \\ Sara E. Simonson
}

Received: 27 October 2005 / Accepted: 27 September 2006 / Published online: 6 February 2007

(C) Springer Science + Business Media B.V. 2007 This article is a U.S. government work, and is not subject to copyright in the United States.

\begin{abstract}
Land managers need cost-effective and informative tools for non-native plant species management. Many local, state, and federal agencies adopted mapping systems designed to collect comparable data for the early detection and monitoring of non-native species. We compared mapping information to statistically rigorous, plot-based methods to better understand the benefits and compatibility of the two techniques. Mapping non-native species locations provided a species list, associated species distributions, and infested area for subjectively selected survey sites. The value of this information
\end{abstract}

D. T. Barnett $(\bowtie) \cdot$ S. E. Simonson

Natural Resource Ecology Laboratory,

Colorado State University,

Fort Collins, CO 80523, USA

e-mail: barnett@nrel.colostate.edu

T. J. Stohlgren · C. S. Jarnevich · T. R. Davern

National Institute of Invasive Species Science,

Fort Collins Science Center, US Geological Survey,

2150 Centre Ave, C,

Fort Collins, CO 80526, USA

G. W. Chong

Northern Rocky Mountain Science Center,

US Geological Survey,

Bozeman, MT 59717, USA

\section{J. A. Ericson}

National Invasive Species Program, National Wildlife

Refuge System, US Fish and Wildlife Service,

Arlington, VA 22203, USA may be compromised by crude estimates of cover and incomplete or biased estimations of species distributions. Incorporating plot-based assessments guided by a stratified-random sample design provided a less biased description of non-native species distributions and increased the comparability of data over time and across regions for the inventory, monitoring, and management of non-native and native plant species.

Keywords Invasive species - Non-native species · Mapping $\cdot$ Inventory $\cdot$ Monitoring

\section{Introduction}

The impacts of invasive species on the environment, human health, and the economy continue to garner attention from public and private agencies, scientists, and the media. Species invasions threaten endangered species, and, behind habitat loss, pose the second most important threat to biodiversity (Randall 1996; Wilcove et al. 1998). Non-native plant species affect native species through direct competition (Westbrooks 1998), altering ecological processes such as hydrologic (Mack et al. 2000) and nutrient cycles (Vitousek et al. 1987), and changing fire and other disturbance regimes (D'Antonio and Vitousek 1992; D'Antonio et al. 1999). Best estimates suggest that invasive species cost 120 billion dollars a year in loss of production of crop lands, herbicide and pesticide 
expenses, and documented containment efforts (Pimentel et al. 2005), and invasive plant species cost the western US economy 34 billion dollars per year (Pimentel et al. 2000). Invasions occur when species are transported to, and establish in new and often distant ranges (Elton 1958; Mack et al. 2000); we refer to plant species undergoing this process as weeds, invasive, exotic, and non-native plant species.

Agencies and individuals charged with managing invasive species often face this daunting challenge with limited budgets and insufficient information and tools. These shortfalls force triage. Priorities must be established and backed (National Invasive Species Council 2003) by scientific, efficient inventory and monitoring systems and decision support tools (Hobbs and Humphries 1995; FICMNEW 2003; Parker et al. 1999).

Efficient management tools must address multiple phases of plant species invasion at local, regional, and landscape scales. Prevention is the first defense (FICMNEW 2003; National Invasive Species Council 2003), but multiple pathways of invasion make the interception of all species unrealistic (Simberloff 2003). Early detection improves efforts to prevent invasive species establishment (FICMNEW 2003; Kaiser 1999), but the small and isolated populations that make new invaders susceptible to eradication also challenge detection and often go unnoticed (Menges 1996; Schemske 1994). At local scales, survey methods must detect new and existing infestations, track population expansion, and direct and evaluate control. Disseminating information allows regional coordination of control and analysis of pathways, barriers, and trends at national scales (Schnase et al. 2002).

To understand non-native plant invasions at local and regional scales, many agencies and organizations developed systems for mapping and compiling nonnative plant species information. Mapping records what, how much, and where non-native species exist on a landscape, and, when implemented over time and space, monitors patches of weeds, helps predict the spread of species, facilitates the exchange of data between agencies, and increases public and political awareness (Roberts et al. 1999). Popular methods provide little or no information about where to sample on a landscape resulting in a subjective sample based on expert opinion. Instead, directions focus on the collection of common data elements to ensure that consistent and comparable data are collected and compiled for non-native plant management in counties (e.g., Freemont County 2006; Salt Lake County 2006), weed management areas (e.g., Mojave Weed Management Area 2006), states (DiPietro et al. 2002; Roberts et al. 1999; State of Colorado Department of Agriculture 2005), Federal Agencies like the US Forest Service (Olivarez and Beard 2000), the National Park Service (Hiebert 2000), and the Bureau of Land Management (Reuwsaat et al. 2000), and North America (North American Weed Mapping Association 2002). While consistency makes information comparable across agencies and projects, the data are not directly comparable to plot-based inventory and long-term monitoring programs in place across the country (Frayer and Furnival 1999; Stohlgren et al. 1999, 2002).

Small-scale experiments (Burke and Grime 1996; Kennedy et al. 2002; Tilman 1999) and landscapescale vegetation surveys (Cleland et al. 2004; Sax 2002) evidence the value of plot-based vegetation studies. Multi-scale vegetation plots capture information on native and non-native species patterns and accurately describe local and landscape conditions and speciesenvironment relationships (Brown and Peet 2003; Keeley et al. 2003; Stohlgren et al. 1995, 1997c, 2002). Spatially explicit data collected within a specific area are repeatable and comparable across space and time (Adler and Lauenroth 2003), making plot data suitable for monitoring non-native species composition, expansion (Blossey 1999; Cleland et al. 2004; Parker et al. 1999) and impacts on native species (FICMNEW 2003; Hastings et al. 2005).

The popularity of mapping systems prompted us to explore the incorporation of plot data with map- ping assessments. We sampled vegetation on two National Wildlife Refuges with stratified-random and gradient sampling designs and mapped non-native plant species to compare the data from mapping and plot-based techniques. Our specific objective was to evaluate the ability of plot data to augment mapping data to improve management of non-native plant species at a variety of spatial scales.

\section{Materials and Methods}

2.1 The National Wildlife Refuge invasive species program

Within the US Fish \& Wildlife Service, the National Wildlife Refuge System (NWRS) manages over 39 
million acres distributed over 545 refuges, 37 wetland management districts, and 50 coordination areas with a mission to restore, protect, and manage habitat for wildlife in the United States. Invasive species pose one of the most significant and most well-recognized threats to the mission of the NWRS. The NWRS National Invasive Species Program provides strategic support and coordination for refuges, organizes volunteer efforts, and, when possible, directly funds non-native species research and control on individual refuges determined to be especially vulnerable to invasion and the impacts of invasive species. We used plant inventory data from The National Elk Refuge and Lacreek National Wildlife Refuge to compare and contrast the value of mapping and plot data.

\subsection{The National Elk Refuge}

The National Elk Refuge covers 9,720 ha in northwest Wyoming, USA. The Refuge exits between 1,920 and 2,164 m elevation in a valley adjacent to the Teton Mountain range in Grand Teton National Park to the northwest, the Gros Ventre Mountains in the BridgerTeton National Forest to the east, and the town of Jackson, Wyoming to the south. Grasslands, sagedominated shrub, and sparse forests provide winter habitat for the Jackson Elk Herd and habitat for endangered species, birds, fish, and other big game animals.

In July and August 2005, we located non-native plant species using mapping techniques, and sampled native and non-native plant species with plots according to a stratified-random sampling design. To evaluate and compare independent mapping efforts, we also acquired mapping data collected on the National Elk Refuge by refuge staff and Teton County Weed and Pest from 1999 to 2004. The data were compiled and distributed by the Greater Yellowstone Coordinating Committee's Invasive Species Working Group (Greater Yellowstone Coordinating Committee 2006).

Our 2005 effort mapped non-native plant species using hand-held computers connected to global positioning system (GPS) receivers according to standards established by the North American Weed Mapping Association (North American Weed Mapping Association 2002). We collected species identity, cover, and location in the field. Smaller patches or single individuals were recorded as a single point, and 'gross area' (general area occupied but not entirely covered by the species), 'infested area' (subset of gross area that is occupied by a non-native plant species), and 'cover' (of species in the infested area) were recorded. We recorded larger patches as a polygon by mapping the perimeter of the patch and estimating 'infested area' and 'cover'.

The five vegetation types in the National Elk Refuge vegetation map (Table 1) provided the basis for a stratified-random sampling design for multiscale plot location (Stohlgren 2006). We sampled 63, $168-\mathrm{m}^{2}$ circular, multi-scale vegetation plots modified from the National Forest Service Inventory and Analysis Program (Frayer and Furnival 1999; Fig.1). Species composition, foliar cover, and cover of abiotic variables (e.g., rock, bare soil, litter) were recorded in three $1-\mathrm{m}^{2}$ subplots and species composition was recorded in the entire $168-\mathrm{m}^{2}$ plot.

\subsection{Lacreek National Wildlife Refuge}

Lacreek National Wildlife Refuge is located in southwestern South Dakota, USA. The 6,640 ha refuge sits on the northern edge of the Nebraska Sandhills and includes native sandhills, meadows, fresh water lakes and marshes, and tall and mixed grass prairie uplands. The refuge provides migration
Table 1 The cumulative and mean number of native and non-native species by vegetation type sampled in circular plots at the National Elk Refuge, Wyoming

\begin{tabular}{llllll}
\hline $\begin{array}{l}\text { Vegetation } \\
\text { type }\end{array}$ & $\begin{array}{l}\text { Number of } \\
\text { plots }\end{array}$ & $\begin{array}{l}\text { Cumulative } \\
\text { native } \\
\text { species }\end{array}$ & $\begin{array}{l}\text { Mean } \\
\text { native } \\
\text { species/plot }\end{array}$ & $\begin{array}{l}\text { Cumulative } \\
\text { non-native } \\
\text { species }\end{array}$ & $\begin{array}{l}\text { Mean } \\
\text { non-native } \\
\text { species/plot }\end{array}$ \\
\hline Cultivated & 5 & 40 & 8 & 16 & 3 \\
Grassland & 26 & 137 & 5 & 30 & 2 \\
Shrubland & 14 & 135 & 10 & 25 & 2 \\
Wetland & 8 & 86 & 11 & 24 & 3 \\
Woodland & 10 & 115 & 12 & 31 & 3 \\
\hline
\end{tabular}




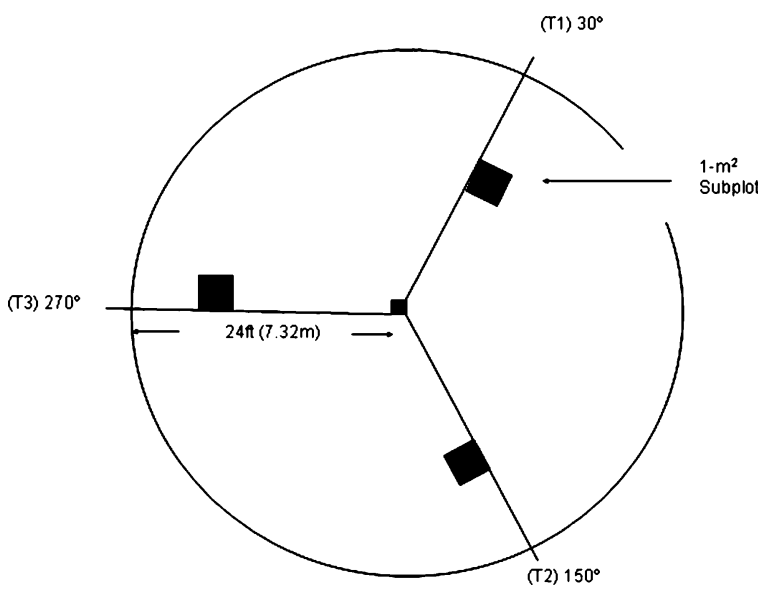

Fig. 1 The circular, multi-scale vegetation plot used to sample native and non-native plant species

habitat for sandhill cranes, Canada geese, shorebirds and neotropical migrants as well as winter habitat for the high planes trumpeter swan.

Like the National Elk Refuge, plot sampling followed a stratified-random design based on the refuge vegetation map. Nine vegetation types were selected for sampling (Table 2). In 2002, we sampled 38 of the $168-\mathrm{m}^{2}$ circular, multi-scale vegetation plots (Frayer and Furnival 1999; Fig. 1). Species composition, foliar cover, and cover of abiotic variables (e.g., rock, bare soil, litter) were recorded in three $1-\mathrm{m}^{2}$ subplots and species composition was recorded in the entire $168-\mathrm{m}^{2}$ plot. We also mapped cheatgrass (Bromus tectorum) with handheld computers and GPS units according to the NAWMA (http://www.NAWMA.org) standards in the sandhills vegetation type.
2.4 Modeling spatial variability on the National Elk Refuge

The spatial models employed require independent variables that describe variability across a spatially continuous area. Available continuous independent variables for predicting dependent variables across the National Elk Refuge included slope, elevation, absolute aspect $\left(0-180^{\circ}\right)$, distance to road, distance to water, relative vegetation type moisture class, and remotely sensed data (Normalized Difference Vegetation Index (NDVI), tassel cap bands 1, 2, and 3 representing brightness, greenness, and wetness, respectively (Cambell 2002), and Landsat bands 1, 2, 3, 4, 5, and 7). Variables were assessed for normality and transformed as needed. When variables demonstrated significant cross-correlation, they were removed from the analysis.

Few modeling techniques estimate variability across unsampled regions of a study area without true absence data. Using the presence-only information from the National Elk Refuge 2005 mapping data, we compared bull thistle (Cirsium vulgare) occurrence locations to a geospatial environmental layer to identify a range, or environmental window, of the environmental variables with conditions suitable to invasion by that species (e.g., if bull thistle was mapped between 0 and $20 \mathrm{~m}$ from water, all areas $<20 \mathrm{~m}$ from water were identified as suitable for bull thistle invasion). We then combined these comparisons of bull thistle to each environmental layer to create a surface where each pixel quantified the number of these environmental variables at that

Table 2 The cumulative and mean number of native and non-native species by vegetation type sampled in circular plots at Lacreek National Wildlife Refuge, SD

\begin{tabular}{llllll}
\hline Vegetation type & Number of plots & $\begin{array}{l}\text { Cumulative } \\
\text { native species }\end{array}$ & $\begin{array}{l}\text { Mean native } \\
\text { species/plot }\end{array}$ & $\begin{array}{l}\text { Cumulative } \\
\text { non-native species }\end{array}$ & $\begin{array}{l}\text { Mean non-native } \\
\text { species/plot }\end{array}$ \\
\hline Forbland & 5 & 60 & 12 & 15 & 3 \\
Upland grassland & 7 & 36 & 5 & 13 & 2 \\
Mesic shrubland & 4 & 71 & 18 & 10 & 3 \\
Upland shrubland & 3 & 21 & 7 & 15 & 5 \\
Mesic woodland & 4 & 58 & 8 & 16 & 4 \\
Sandhills & 6 & 45 & 7 & 8 & 3 \\
Prarie dog towns & 3 & 21 & 8 & 9 & 3 \\
Mesic grasslands & 3 & 23 & 7 & 2 & 1 \\
Wet herbaceous vegetation & 3 & 21 & &
\end{tabular}


location that were outside the range of the presence envelope for the Refuge.

We applied the same technique to evaluate each of the dataset's abilities to cover the environmental variability of the National Elk Refuge. Instead of bull thistle, we combined comparisons of the 1999-2004 mapping data, the plot data alone, the 2005 mapping data alone, and the combination of the plot and 2005 mapping data to each environmental layer to create a surface where each pixel quantified the number of variables at that location that were outside the range of sampled environmental variability. For example, the Refuge has an elevation range of 1,920-2,164 m but if the 1999-2004 mapping survey efforts only sampled at elevations between 1,901 and 2,045 m, any pixel with elevation values greater than 2,045 were classified as being outside the sampled range of potential elevation variability; one of the potential 15 environmental variables.

We used plot-based data to increase our ability to model the variability of non-native plant species cover on the National Elk Refuge. After eliminating crosscorrelated independent variables, we used multiple regression analysis (Reich and Davis 1998) to evaluate coarse-scale variability with a stepwise procedure to select the independent variables to include in the regression model. We then modeled the error (i.e., residuals) from the regression model with a binary regression tree (De'ath and Fabricius 2000), and avoided over-fitting the model with a 10 fold cross-validation procedure to identify the tree size that minimized the total deviance associated with the tree. We generated a grid representing non-native species cover using parameter estimates from the regression model. Passing the appropriate independent variables through the regression tree created a grid representing the error in the regression model. A sum of the two grids amounted to the final surface of predicted non-native plant species cover (Reich et al. 2004).

We combined data from the National Elk Refuge plot and mapping methods to create a probability model of species occurrence. Logistic regression is a type of general linear model (GLM) appropriate for data with a binary distribution such as species presence or absence (McCullagh and Nelder 1989). For whitetop (Cardaria draba), logistic regression used a logit link function that assumed a binomial distribution (Statistical Sciences 2005). We limited independent variables by removing highly correlated variables and we selected variables with explanatory power using a stepwise procedure for GLM in S-plus (Statistical Sciences 2005). The probability surface was generated using the predictor variable raster layers with the statistical output from S-plus. The resulting cell values were in the logit scale and were therefore back-transformed to the original scale of the probability surface using:

$p=\frac{e^{(\mathrm{LP})}}{1+e^{(\mathrm{LP})}}$

where $p$ is the probability and LP is the linear predictor.

\section{Results}

\subsection{The National Elk Refuge}

During the years 1999-2004, the National Elk Refuge and Teton County mapped 21 non-native plant species at 458 locations on the Refuge (USDA 2005). The infested area totaled 110.8 ha $(\mu=0.24$, $\mathrm{SE}=0.01$ ). Nodding plumeless thistle (Carduus nutans) was the most frequently mapped species (179 locations) and also had the largest infested area (46.1 ha, $\mu=0.24, \mathrm{SE}=0.02$ ).

Our 2005 non-native plant species mapping effort recorded 1,851 non-native plant locations and recorded 38 non-native plant species (Table 3). Mapped gross area of all patches totaled 88.6 ha with a mean patch size of 0.05 ha $(\mathrm{SE}=0.002)$. Of that area, the infested area amounted to 12.7 ha $(\mu=0.01$, $\mathrm{SE}=0.001)$ with a mean cover of $18.6 \%(\mathrm{SE}=0.6)$. Nodding plumeless thistle was the most frequently mapped species (530 locations) and cheatgrass had the largest infested area (4.5 ha, 438 locations). Oxeye daisy (Leucanthemum vulgare), Russian olive (Elaeagnus angustifolia), and sulphur cinquefoil (Potentilla recta) were the only species mapped a single time.

In our 2005 plot-based survey, we identified a total of 332 species in the $63168-\mathrm{m}^{2}$ plots. The NRCS PLANTS Database (USDA 2005) listed 47 (Table 3) of these as non-native plant species. While the sampling effort was not equitable across each vegetation type (Table 1), we found more cumulative and non-native species per plot in the woodland vegeta- 
tion type (Table 1). Individual plots in the woodland (10 plots, 17 non-native species) and wetland (two plots, each with 16 non-native species) vegetation types contained the most non-native species.

Yellow salsify (Tragopogon dubius) occurred with the highest frequency (44 plots) followed by common dandelion (Taraxacum officinale, 41 plots) and Kentucky bluegrass (Poa pratensis, 40 plots). Many (14) non-native species occurred on only one plot (Table 3).

Non-native species that occurred only in the large plot (Fig. 1; 13 species) do not have cover values. Of the 28 non-native species occurring in subplots, smooth brome (Bromus inermis) had the highest mean cover, followed closely by cheatgrass. Mean cover values for a single plot for these species frequently reached values $>60 \%$, especially in the shrub, wood, and grassland vegetation types. On the other end of the spectrum, a majority of the nonnative species had cover values less than $5 \%$ (Table 3).

\subsection{Lacreek National Wildlife Refuge}

We recorded a total of 205 species on 38 plots. The NRCS PLANTS Database (USDA 2005) categorized 27 of these species as non-native plant species (Table 3). The highest number of total species per plot was recorded in the mesic woodland vegetation type (Table 2). The plot with the fewest number of species was in a wet herbaceous vegetation type because it was dominated by Jerusalem artichoke (Helianthus tuberosus) and Sartwell's sedge (Carex sartwellii). A plot in the forbland vegetation type was the most invaded, while three plots were not invaded at all (one each in the sandhills, forbland, and wet herbaceous vegetation types; Table 2). Highly invaded vegetation types included the mesic woodland, forbland, upland shrubland, upland grassland, and the mesic grassland, which had an intermediate number of non-native plant species (Table 2).

Kentucky bluegrass (Poa pratensis) was found on almost half of the plots (19 plots). Other frequently detected non-native plant species included Canada thistle (Cirsium arvense, 18 plots) and smooth brome (15 plots), while seven non-native species were found on only one plot (Table 3). Many species with higher frequency rates had relatively high cover values ( $R=0.2, p<0.01, n=133$; Kentucky bluegrass (Poa
Pratensis), smooth brome, and crested wheatgrass (Agropyron cristatum)). However, kochia (Kochia scoparia) and stinging nettle (Urtica dioica) had high cover values but occurred on few plots.

Cheatgrass was found on only four plots, primarily in a localized area of the sandhills vegetation type. We mapped cheatgrass at 24 locations totaling $<0.2$ ha infested area with a mean cover of $51.2 \%$ $(\mathrm{SE}=5.3)$.

3.3 Modeling spatial variability on the National Elk Refuge

Collecting presence data by mapping patches limited our ability to predict the distribution of species across the unsampled landscape because we were unable to discern absence locations (where the species truly was absent) from unsurveyed areas. Evaluation of the presence of bull thistle against each of these variables resulted in a surface where pixels were defined by the number of layers that pixel was outside the observed sampled range (Fig. 2). A pixel with a score of zero has a higher probability of containing bull thistle than a pixel with a value greater than zero.

The evaluation of each inventory effort relative to the variability of each of the environmental variables for the National Elk Refuge provided surfaces that defined the number of variables with values outside the sampled environmental envelope (Fig. 5). For comparing the different datasets, we calculated the number of pixels with environmental variables outside the range of the sampled variability (Table 4).

Development of the modeled surface of nonnative plant species cover involved two steps. First, the independent variables selected in the regression to describe coarse-scale variability included the $\log$ of relative vegetation moisture, $\log$ of distance to water, the square root of the distance to road, and Landsat band 4 (cover $=-6.6776-19.1116$ (vegetation moisture) -7.4117 (distance to water) -0.7397 (distance to road $)+0.4718$ (Landsat 4$)$ ). In the second step, the independent variables were used in the regression tree to model the error of the regression model. The tree size selected to minimize the total deviance in the regression tree was four splits. The regression model alone explained $21 \%$ of the observed variability. The regression tree accounted 
Table 3 The non-native plant species, wildlife refuge, frequency (freq) and mean cover (with standard error) by plot and mapping techniques

\begin{tabular}{|c|c|c|c|c|c|}
\hline Species & Wildlife refuge & Map freq. & Map cover (SE) & Plot freq. & Mean plot cover (SE) \\
\hline Achillea millefolium & National Elk & & & 28 & $2.0(0.5)$ \\
\hline Acroptilon repens & National Elk & 6 & $1.5(0.9)$ & & \\
\hline \multirow{2}{*}{ Agropyron cristatum } & National Elk & 2 & $50(0)$ & 16 & $16.8(7.0)$ \\
\hline & Lacreek & & & 11 & $34.29(28.2)$ \\
\hline Alopecurus pratensis & National Elk & & & 1 & \\
\hline Alyssum alyssoides & National Elk & & & 1 & \\
\hline Alyssum desertorum & National Elk & & & 21 & $3.8(0.9)$ \\
\hline Amaranthus retroflexus & Lacreek & & & 1 & \\
\hline Arabis hirsuta & National Elk & & & 5 & $1.8(1.3)$ \\
\hline Arctiumminus & Lacreek & & & 2 & \\
\hline Artemisiabiennis & Lacreek & & & 1 & $0.33(0.6)$ \\
\hline Berteroa incana & National Elk & 5 & $7.8(3.0)$ & & \\
\hline \multirow[t]{2}{*}{ Bromus inermis } & National Elk & 1 & $40(0)$ & 21 & $30.1(14.3)$ \\
\hline & Lacreek & & & 15 & $19.93(27.8)$ \\
\hline Bromus japonicus & National Elk & 2 & $10(0)$ & 5 & $0.5(0)$ \\
\hline \multirow{2}{*}{ Bromus tectorum } & National Elk & 438 & $28.9(1.4)$ & 10 & $29.9(11.3)$ \\
\hline & Lacreek & 24 & $51.25(5.3)$ & 4 & $5(7.4)$ \\
\hline Camelina microcarpa & National Elk & 6 & $33.3(11.6)$ & 6 & $0.5(0)$ \\
\hline Cardaria chalapensis & National Elk & & & 2 & $2.5(1.8)$ \\
\hline Cardaria draba & National Elk & 60 & $4.6(1.3)$ & & \\
\hline Carduus nutans & National Elk & 545 & $9.4(0.5)$ & 4 & $4.0(0)$ \\
\hline Centaurea diffusa & National Elk & 48 & $0.2(0.1)$ & 1 & $2.5(0)$ \\
\hline Centaurea maculosa & National Elk & 56 & $8.8(1.0)$ & 1 & \\
\hline Centaurea scabiosa & National Elk & 41 & $6.8(1.4)$ & & \\
\hline Cerastium fontanum baumg. ssp. Vulgare & National Elk & & & 1 & $1.25(0)$ \\
\hline \multirow{2}{*}{ Chenopodium album } & National Elk & & & 1 & \\
\hline & Lacreek & & & 4 & $0.67(1.2)$ \\
\hline Chorispora tenella & National Elk & & & 1 & \\
\hline \multirow[t]{2}{*}{ Cirsium arvense } & National Elk & 260 & $7.7(0.4)$ & 9 & $12.8(4.3)$ \\
\hline & Lacreek & & & 18 & $3.63(5.2)$ \\
\hline Cirsium vulgare & National Elk & 23 & $6.4(1.4)$ & 2 & $1.5(0)$ \\
\hline Crepis tectorum & National Elk & & & 2 & \\
\hline Descurainia sophia & National Elk & 63 & $23.4(2.7)$ & 3 & 42.0 \\
\hline Echinochloa crus-galli & Lacreek & & & 4 & \\
\hline Elaeagnus angustifolia & National Elk & 1 & $10(0)$ & & \\
\hline Elymus junceus & National Elk & & & 1 & \\
\hline Elymusrepens & Lacreek & & & 2 & $24.83(36.4)$ \\
\hline Heracleum sphondylium & National Elk & & & 1 & \\
\hline Hieracium cynoglossoides & National Elk & 46 & $2.0(0.4)$ & & \\
\hline Humulus lupulus & Lacreek & & & 2 & $20.5(24.7)$ \\
\hline Hyoscyamus niger & National Elk & 6 & $1.7(0.8)$ & & \\
\hline Kochia scoparia & Lacreek & & & 9 & $31.17(37.9)$ \\
\hline \multirow[t]{2}{*}{ Lactuca serriola } & National Elk & 18 & $13.6(1.8)$ & 12 & $1.6(0.6)$ \\
\hline & Lacreek & & & 7 & $4.42(8.1)$ \\
\hline Lappula redowskii & National Elk & 22 & $15.4(3.7)$ & & \\
\hline Lappula squarrosa & National Elk & & & 1 & $0.5(0)$ \\
\hline Lepidium latifolium & National Elk & 14 & $20.6(2.4)$ & 1 & \\
\hline Lepidium perfoliatum & National Elk & 2 & $25(0)$ & & \\
\hline Leucanthemum vulgare & National Elk & 1 & $2.0(0)$ & & \\
\hline Linaria dalmatica & National Elk & 52 & $4.8(1.5)$ & & \\
\hline Linaria vulgaris & National Elk & 9 & $10(4.9)$ & & \\
\hline
\end{tabular}


Table 3 (continued)

\begin{tabular}{|c|c|c|c|c|c|}
\hline Species & Wildlife refuge & Map freq. & Map cover (SE) & Plot freq. & Mean plot cover (SE) \\
\hline Medicago lupulina & National Elk & 27 & $26.5(3.4)$ & 11 & $15.2(7.7)$ \\
\hline Medicago sativa & National Elk & & & 8 & $11.6(7.1)$ \\
\hline Melilotus albus & National Elk & 2 & $80.0(0)$ & 8 & $9.2(8.0)$ \\
\hline \multirow[t]{2}{*}{ Melilotusofficinalis } & National Elk & 17 & $28.5(7.5)$ & 11 & $6.4(3.8)$ \\
\hline & Lacreek & & & 9 & $0.33(0.5)$ \\
\hline Nepetacataria & Lacreek & & & 1 & \\
\hline \multirow[t]{2}{*}{ Phleum pratense } & National Elk & & & 10 & $2.9(1.2)$ \\
\hline & Lacreek & & & 1 & \\
\hline Poа аппиа & National Elk & & & 2 & $38.0(0)$ \\
\hline Poa bulbosa & National Elk & & & 2 & $1.75(0)$ \\
\hline \multirow[t]{2}{*}{ Poa pratensis } & National Elk & 1 & $20(0)$ & 40 & $14.4(3.2)$ \\
\hline & Lacreek & & & 19 & $12.39(16.7)$ \\
\hline Poa trivialis & National Elk & & & 1 & 0.5 \\
\hline Polygonum convolvulus & Lacreek & & & 4 & $0.33(0.6)$ \\
\hline Potentilla recta & National Elk & 1 & 1.0 & & \\
\hline Rumex aquaticus & National Elk & 21 & $6.0(3.2)$ & & \\
\hline Rumex crispus & Lacreek & & & 5 & $1.17(2.4)$ \\
\hline Salixfragilis & Lacreek & & & 1 & $33.33(57.7)$ \\
\hline Sisymbrium altissimum & National Elk & 43 & $26.3(2.7)$ & 5 & $11.8(7.1)$ \\
\hline \multirow[t]{2}{*}{ Sonchus arvensis } & National Elk & 5 & $32.0(11.1)$ & 1 & \\
\hline & Lacreek & & & 7 & $3.75(4.8)$ \\
\hline Sonchus uliginosus & National Elk & 11 & $46.8(11.9)$ & & \\
\hline Tanacetum vulgare & National Elk & 9 & $1.7(0.4)$ & & \\
\hline Taraxacum laevigatum & National Elk & & & 2 & $7.0(5.0)$ \\
\hline \multirow[t]{2}{*}{ Taraxacum officinale } & National Elk & 7 & $14.6(3.5)$ & 41 & $1.8(0.4)$ \\
\hline & Lacreek & & & 7 & $0.67(1.2)$ \\
\hline Thlaspi arvense & National Elk & 33 & $13.2(2.2)$ & 9 & $0.8(0.1)$ \\
\hline \multirow[t]{2}{*}{ Tragopogon dubius } & National Elk & 23 & $12.7(3.9)$ & 44 & $1.3(0.2)$ \\
\hline & Lacreek & & & 3 & $0.33(0.5)$ \\
\hline Trifolium hybridum & National Elk & & & 6 & $3.0(0)$ \\
\hline Trifolium pratense & National Elk & & & 3 & \\
\hline Trifolium repens & National Elk & & & 3 & $1.0(0)$ \\
\hline Triticum aestivum & National Elk & & & 1 & \\
\hline Typha angustifolia & Lacreek & & & 1 & $0.33(0.6)$ \\
\hline \multirow[t]{2}{*}{ Urtica dioica } & National Elk & & & 2 & \\
\hline & Lacreek & & & 7 & $38.83(40.1)$ \\
\hline Verbascum thapsus & National Elk & 9 & $2(0.4)$ & & \\
\hline Veronica biloba l. & National Elk & & & 2 & $0.5(0)$ \\
\hline
\end{tabular}

for an additional $57 \%$ of the unexplained variability for an overall model explanation of $78 \%$ of the variance $\left(R^{2}=0.78\right.$; Fig. 3$)$.

To model the probability of occurrence of whitetop, the General Linear Model (GLM) stepwise regression selected seven independent variables (absolute aspect, square root of distance to road, log of the slope, relative vegetation moisture, Landsat bands 1 and 5, and tassel cap wetness). Coefficients reflect the logit function, not the original scale. They were both positive and negative and the slope $(-4.1)$ had the strongest effect. The model had a null deviance of 169.1 and a residual deviance of 84.6 , so the model explained $50 \%$ of the deviance $\left(D^{2}=0.50\right.$; Fig. 4$)$.

\section{Discussion}

We present two very different approaches to reach a single objective: landscape-scale invasive plant spe- 


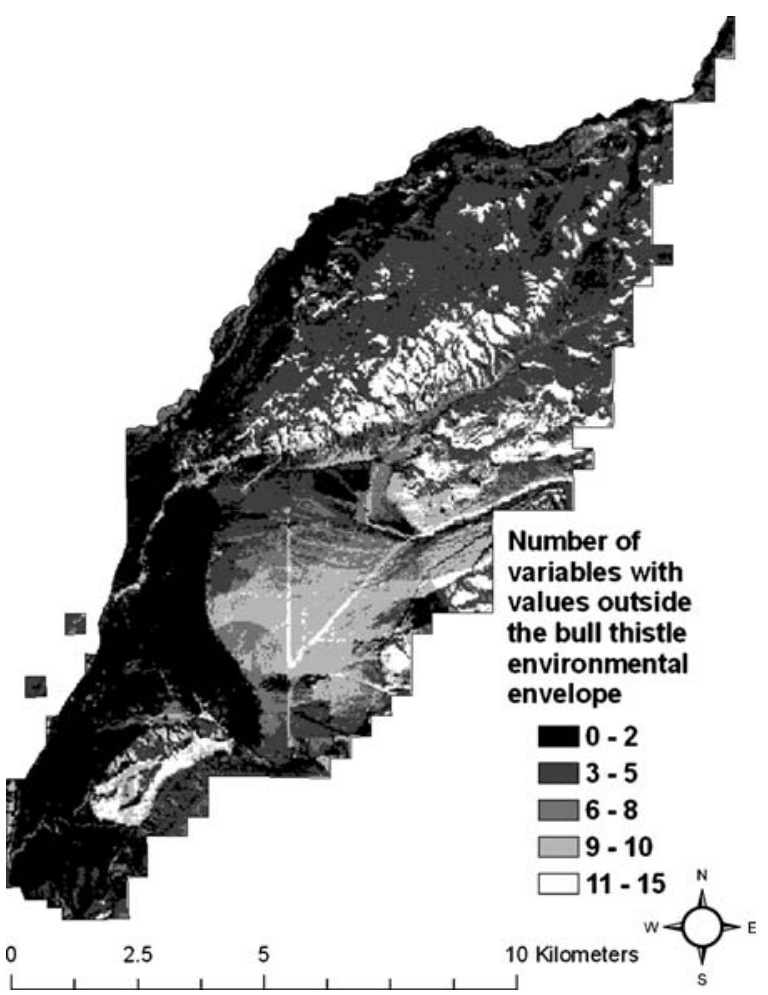

Fig. 2 A comparison of bull thistle (Cirsium vulgare) to 15 environmental variables. Pixels are colored according to the number of variables at that location that were outside the range of the environmental variability for the species presence. Darker shades describe areas more vulnerable to invasion by bull thistle

cies inventory. Given ecological urgency and limited funding, no effort can afford to inventory an entire landscape (Stohlgren 2006). What did we miss? To evaluate the two approaches (mapping and plot sampling), we assessed the strengths and weaknesses of the two inventory techniques' ability to realistically describe non-native plant species distributions across the landscape. Because each technique described the invasion picture differently, we examined the synergy of combining information from each to improve inventory and assist management with early detection, predicting species distributions, setting priorities for control and restoration, and data comparability.

\subsection{Mapping data}

We evaluated two very different mapping datasets of the same landscape. The data collected between 1999 and 2004 by Teton County and the National Elk Refuge is typical of many mapping efforts stretched thin by limited funding and other priorities, and is useful for comparison to our independent 2005 mapping effort. The 2005 mapping effort provides comprehensive coverage of the National Elk Refuge and an appropriate dataset for evaluation of strengths and weaknesses and comparison to the plot-based inventory effort.

Identifying the composition and distribution of non-native plant species provides a foundation for setting priorities for control and restoration. Uninhibited by sample design, mapping and targeted surveys can serve as a tool for early detection; they resemble rare native plant surveys that locate rare species or, in this case, detect new invasive plant species (Menges 1996). The suite of species mapped can be evaluated according to general threat (Table 3; Hiebert 1997; Parker et al. 1999; USDA 2005), and distributions can
Table 4 The total number of $30 \times 30 \mathrm{~m}$ pixels in each inventory surface that describes the environmental variability described by each inventory effort at the National Elk Refuge

\begin{tabular}{lllll}
\hline $\begin{array}{l}\text { Number of environmental variables outside } \\
\text { range of sampled variability }\end{array}$ & $\begin{array}{l}1999- \\
2004\end{array}$ & $\begin{array}{l}2005 \\
\text { map }\end{array}$ & Plots & $\begin{array}{l}\text { Plot and } \\
2005 \text { map }\end{array}$ \\
\hline 0 & 84,497 & 140,328 & 115,468 & 141,068 \\
1 & 32,799 & 2,306 & 17,828 & 1,568 \\
2 & 15,833 & 141 & 2,333 & 139 \\
3 & 8,414 & 153 & 2,528 & 153 \\
4 & 742 & 13 & 2,025 & 13 \\
5 & 318 & 16 & 1,612 & 16 \\
6 & 282 & 2 & 627 & 2 \\
7 & 64 & 0 & 150 & 0 \\
8 & 10 & 0 & 117 & 0 \\
9 & 0 & 0 & 204 & 0 \\
10 & 0 & 0 & 62 & 0 \\
11 & 0 & 0 & 5 & 0 \\
\hline
\end{tabular}




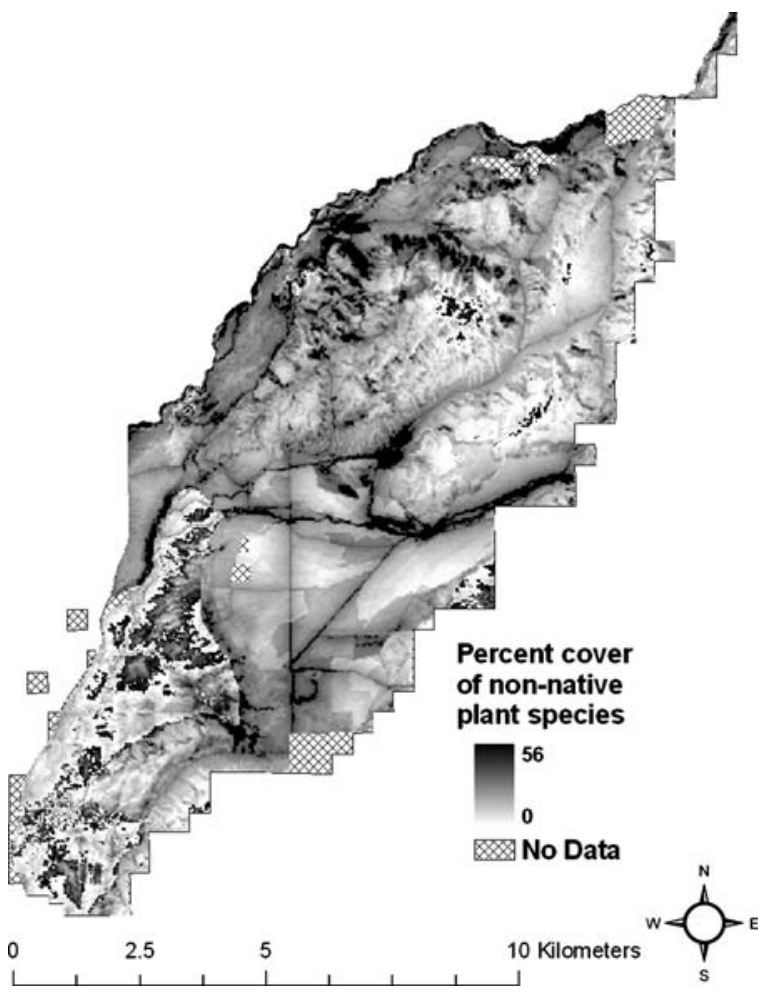

Fig. 3 Predicted cover of non-native plant species in a $1 \mathrm{~m}^{2}$ area on the National Elk Refuge. The model is based on plotbased vegetation sampling

be compared to vulnerable natural resources (Blossey 1999). Regardless of threat, a species with a widespread distribution may be inefficient to control and may be ignored in favor of a rare, non-native species poised to spread across the landscape (Hobbs and Humphries 1995; Sax and Brown 2000).

For example, infrequent detection by mapping, combined with the significant threat to native plant species and state noxious status (Wyoming Department of Agriculture 2006), might qualify butter and eggs (Linaria vulgaris, Table 3 ) as a high priority for control on the National Elk Refuge. While eradication of most widely distributed species may not be costeffective (e.g., nodding plumeless thistle; Table 3), species like cheatgrass with documented distributions that threaten native populations and ecological process may justify containment. Similar to other findings (Pierson and Mack 1990), mapping data suggested higher elevations and areas farther from road disturbance (Gelbard and Belnap 2003) at the National Elk Refuge supported less cheatgrass. This inventory information might focus cheatgrass con- tainment on patch boundaries and elevation constraints identified by the sample of mapped patches.

Comparability leverages information. Data capable of directing control measures on a specific landscape can also facilitate early warning of potential invasions in nearby or similar areas; increase public awareness of non-native species impacts; and direct funding (Carpenter et al. 2002). The local collection of standardized invasive species mapping information across agencies like the National Wildlife Refuge System, counties, and states provides a framework for regional communication. Distribution of simple species lists across boundaries can improve early detection because any inventory has a greater chance of success with an understanding of the composition of the regional non-native species pool (Blossey 1999; Parker et al. 1999).

Comparable metrics specific to mapping programs can assist in addressing invasive species management questions. For example, comparison of frequency and infested area of cheatgrass between the two refuges provided an indication of the threat of cheatgrass at

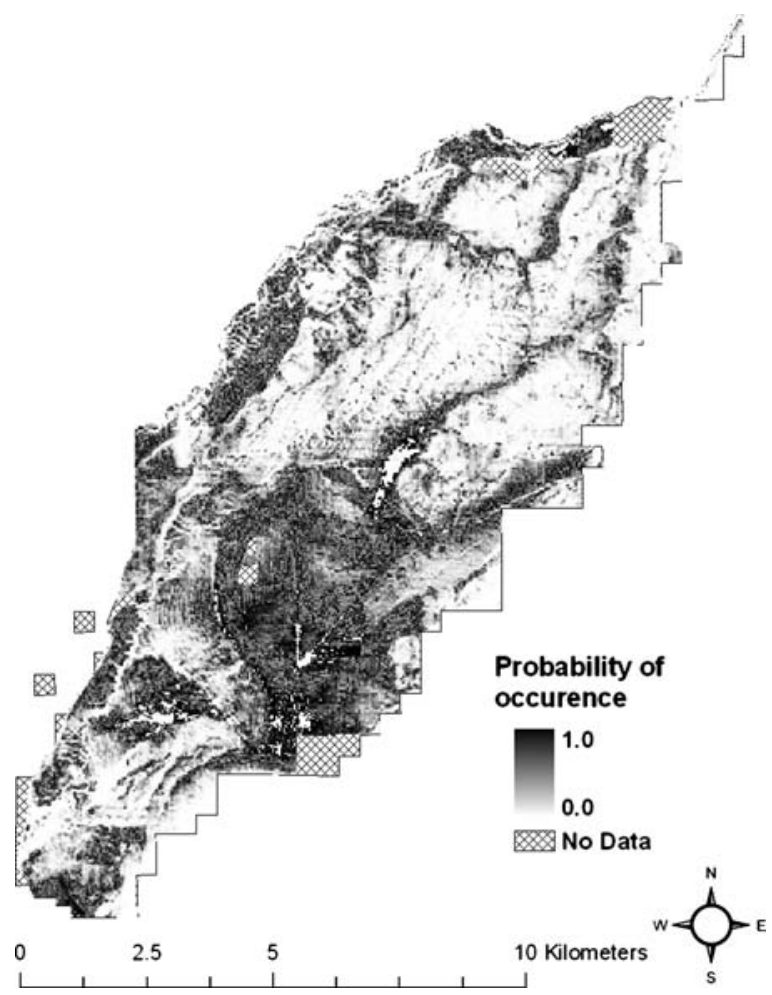

Fig. 4 The probability of occurrence of whitetop (Cardaria draba) based on a combination of plot sampling and mapping data from the National Elk Refuge 
Lacreek National Wildlife Refuge. Cheatgrass at the National Elk Refuge was mapped at 438 locations with an infested area totaling 4.5 ha. The Lacreek National Wildlife Refuge effort reported cheatgrass at 24 locations with a total of 0.15 ha. It could be inferred that cheatgrass is currently a greater problem in the Teton region as compared to the Great Plains, but the propensity of cheatgrass to undergo range expansions underscores the importance of control at Lacreek National Wildlife Refuge while cheatgrass is relatively rare on the landscape.

While some components of the mapping techniques addressed inventory needs, several weaknesses in the approach caused the information to fall short of intended goals. The survey methods defy sample design. Resulting invasive species inventories that fail to exhaustively map an entire landscape may misrepresent the distribution or environmental window of a non-native species, and even miss non-native species (Blossey 1999). Prior to 2005, mapping at the National Elk Refuge from 1999 to 2004 was not directed by a mandate to sample more remote parts of the Refuge or influenced by the plot-based sampling design. The mapping tended to occur at easily accessible areas such as roads and near riparian corridors. Of the 458 mapped locations no sample was more than $830 \mathrm{~m}$ from either a road or stream, and most mapped locations were less than $100 \mathrm{~m}$ from a road or a stream. While roads, disturbed areas (Gelbard and Belnap 2003; Milton and Dean 1998; Parendes and Jones 2000), and riparian areas (DeFerrari and Naiman 1994; Planty-Tabacchi et al. 1996; Stohlgren et al. 1998) tend to harbor non-native plant species, this type of effort presents a biased view of invasion across the landscape: important invaders could be missed, extrapolation to the rest of the landscape is limited, and the sampled areas are inadequate for monitoring invasive plant species over time.

Most inventory efforts cannot afford to inventory an entire landscape (Stohlgren 2006), and attempting to do so may not be an efficient use of resources given the urgency of control and the need for restoration (Parker et al. 1999). By relaxing statistical rigor and ignoring absence data, mapping systems compromise modeling that can estimate distributions across the unsampled landscape. We were able to generate non-statistical distributions of single species based on mapping data (Fig. 2), but the vagaries of cover and multi-species collections associated with mapping prohibited models of cover and non-native species richness.

Standardized mapping provides a framework for collating infested areas and cover across landscapes, but these measures do not establish a system for rigorous inventory or effective monitoring (Hulme 2003). Mapping forces the investigator to make judgment calls: should many small and loosely connected patches of a single species be mapped as separate patches, or should they be lumped into one single large patch? Splitting requires significant time, and defining where one patch begins and another ends can be challenging. Lumping requires estimations of infested area and cover across potentially large areas, and is complicated by variation in patch size. A single estimation of cover for all patches is influenced by the size of the patches and is often inaccurate given the variability of species responses to environmental conditions.

A comparison of the 1999-2004 mapping data to the 2005 mapping data illustrated the difficulty of discerning the subjectivity and rigor of mapping assessments from population changes. In both datasets, nodding plumeless thistle was the most frequently detected species. Despite an increase of 179-530 recorded locations, the infested area of nodding plumeless was significantly greater in the 19992004 dataset (46.1 ha) than in the 2005 mapping effort $(0.63 \mathrm{ha})$. Strict interpretation of the results might suggest an explosion of single individuals across the landscape combined with successful control of the species resulted in the higher frequency and lower cover. However, such an explanation is unlikely, and the disparity likely reflects an inconsistency in data collection and a greater sampling effort in 2005 . This disparity demonstrates the need for more rigorous inventory and monitoring efforts in priority areas.

\subsection{Plot data}

The plot-based assessment pursued the same inventory goals as the mapping inventory with very different results. The plot inventories collected the composition and cover of native and non-native species in a defined and repeatable space at locations directed by a stratified-random sample design. Like mapping or any other method, this quantitatively 


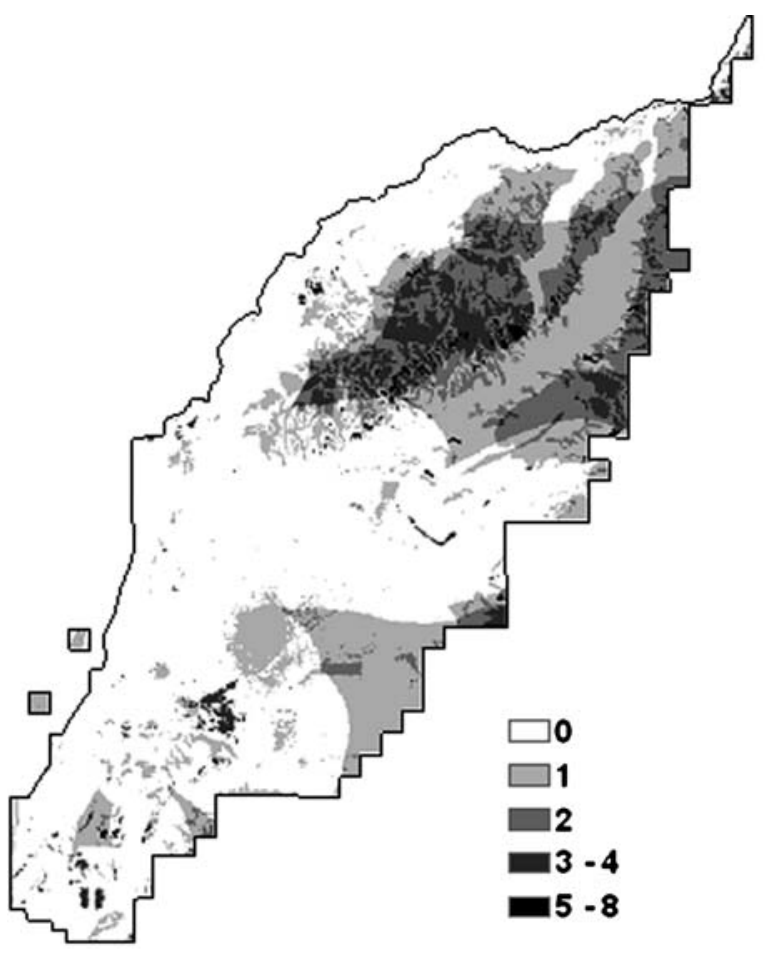

a.

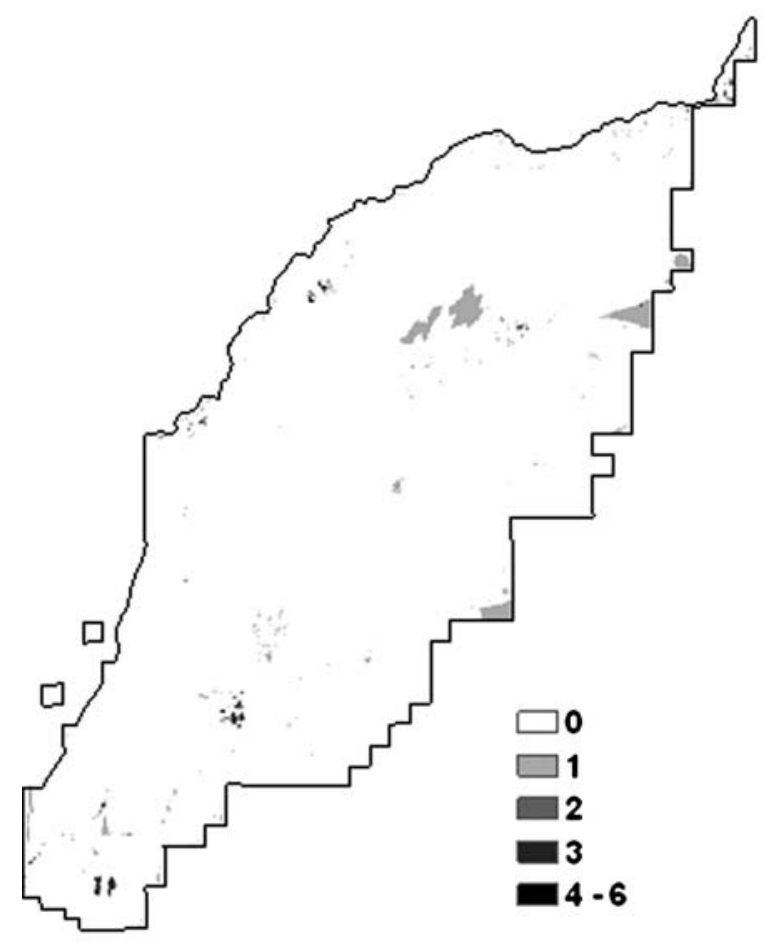

c.

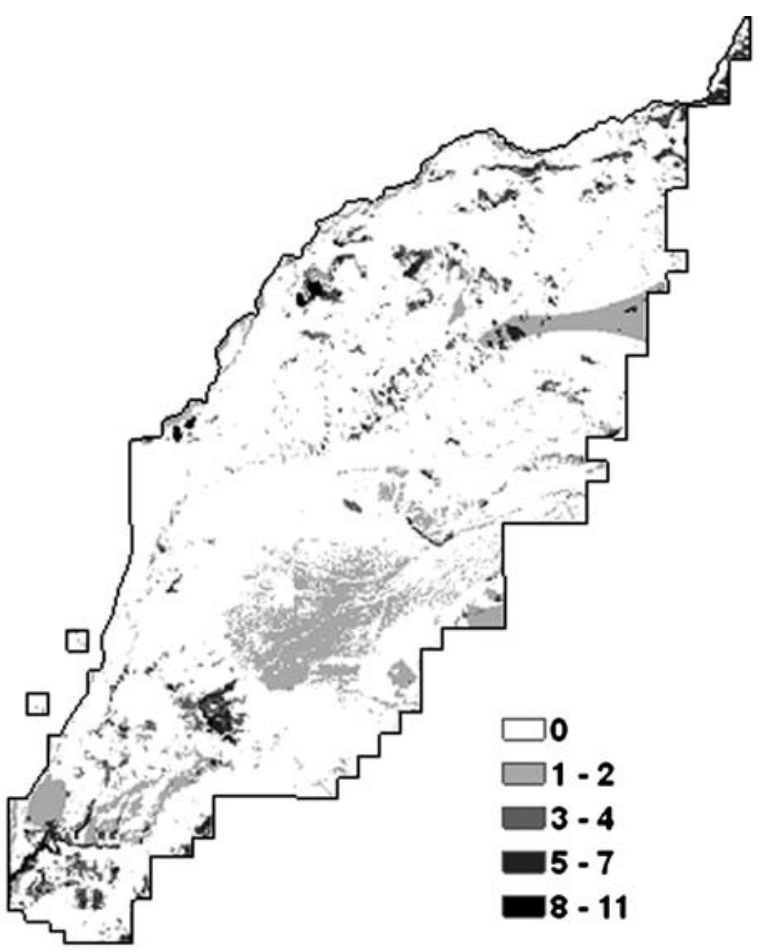

b.

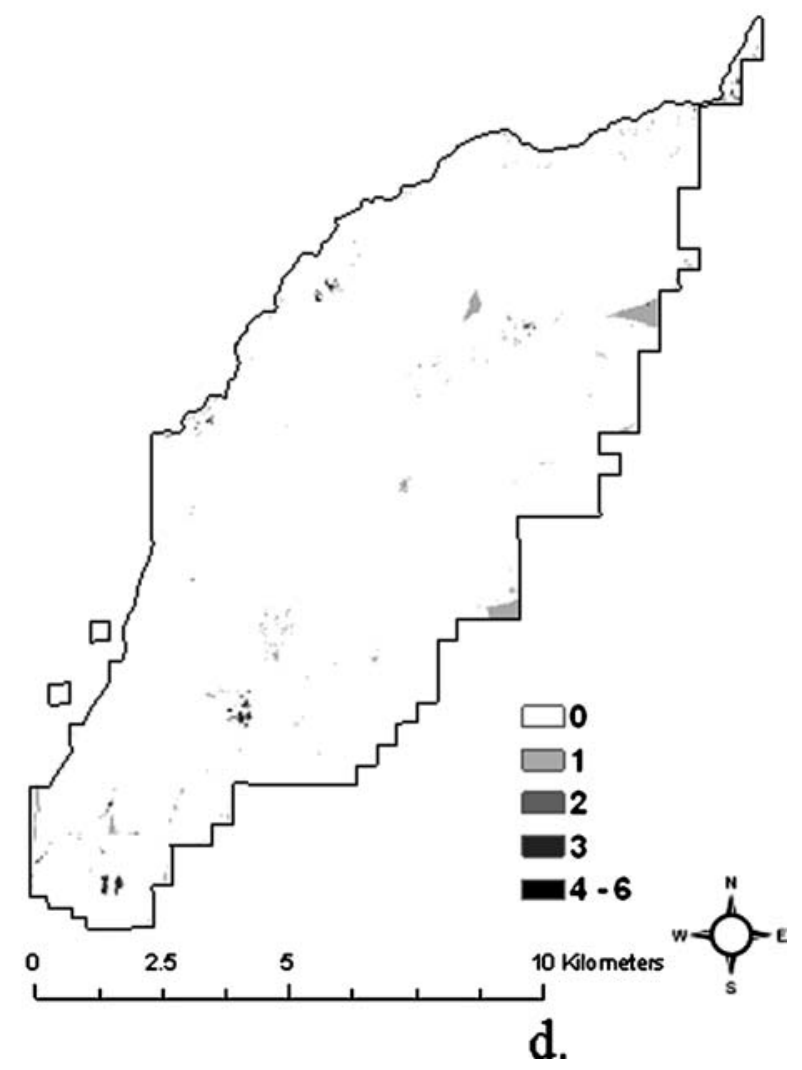


4Fig. 5 The number of variables with values outside the sampling environmental window for the 1999-2004 mapping data (a), the 2005 plot data (b), the 2005 mapping data (c), and a combination of the 2005 plot and mapping data (d). Lighter shades indicate greater coverage of environmental variability

rigorous system displayed a suite of strengths and weaknesses in describing invasive plant species distributions on the landscape.

Stratified-random sampling allowed an unbiased description of invasive species population parameters (Lo and Watson 1998). At both Lacreek National Wildlife and the National Elk Refuges, the sample design forced sampling to remote locations and rare vegetation types (Tables 1 and 2). Left to mapping techniques, some of these may have gone unsampled, missing some non-native species, and compromising the perceived distribution of others. Collecting accurate data in a defined and repeatable plot generates comparable data across both time and space. The fixed sampling unit allowed direct and quantifiable comparison on a single landscape: for example, at the National Elk Refuge the woodland vegetation type was most invaded by non-native plant species (Table 1). At larger scales, plot inventories facilitated the distribution and comparison of information across landscapes: Canada thistle occurred on more plots and invaded more vegetation types at Lacreek National Wildlife Refuge than at the National Elk Refuge. However, the mean cover of Canada thistle was greater at the National Elk Refuge suggesting that while the species was less prevalent on the landscape, patches were denser where they did occur (Table 3). This type of plot-based information and the comparisons they facilitate are not limited to a few National Wildlife Refuges. Numerous inventories (Barnett and Stohlgren 2003; McIntyre and Lavorel 1994; Sax and Brown 2000; Stohlgren et al. 1999; Underwood et al. 2004) have used plots to characterize plant invasions, and the US Forest Service Inventory and Analysis Program employs a series of circular plots across the country (Frayer and Furnival 1999) that are directly comparable to the multi-scale circular plot described in this study.

The comparability of plot data facilitates evaluation of change over time (Cole and Landres 1996; Mack et al. 2000; Stohlgren 2006). Blossey (1999) stressed the need for standardized and well-replicated monitoring studies that hold up to rigorous statistical analysis and interpretation, and others (Hobbs and Humphries 1995; Parker et al. 1999) demonstrated the need to focus on multiple invasive species and inclusion of native species. Resampling multi-scale, spatially-explicit plots provides a repeatable system to monitor plant invasions and assess the effectiveness of control efforts (FICMNEW 2003; Stohlgren et al. 1999). Plots shift the focus from a species-by-species inquiry to an ecosystem approach. The co-occurrence of invasive species, species-environment relationships (Tables 1 and 2), and native species richness, cover, and composition become comparable and repeatable metrics for understanding the impact of invasions both locally and across management units. In addition to assessing the impact of non-native species on native species, managers can assess the impact of control, restoration, and other management activities on native species. Lacreek National Wildlife Refuge aggressively controls Canada thistle. Repeated sampling of treated and non-treated areas could quantify the impact of Canada thistle on native species and the impact of mowing to control Canada thistle on native species. Plot sampling took longer than mapping, but it allowed more questions to be answered: What are the effects of invasion? Which non-native species should I target for control? What habitats are vulnerable to future invasions?

Plot-based sampling can also be used to assess habitat vulnerabilities and statistically predict species distributions. Simple compilations of species occurrence highlighted heavily invaded vegetation types (Tables 1 and 2) and indicated those types vulnerable to invasion (Chong et al. 2006; Godefroid and Koedam 2003). Future inventories and control efforts might do well to focus on these areas, especially since many field studies have shown that areas highly invaded by non-native plant species tend to support greater native plant species richness (Cleland et al. 2004; Sax 2002; Stohlgren et al. 1999). Predictions at finer scales were achieved with statistical models that predicted, for example, the cover of non-native species across the National Elk Refuge landscape (Fig. 3). Not only did this model predict the distribution of species across the unsampled landscape, the significant independent variables provided an indication of the environmental forces controlling invasions on the landscape. The model can be used to efficiently direct further inventory and facilitate early detection (Higgins et al. 1999). 
As with mapping techniques, plot-based inventories must include compromises that amounted to weaknesses in the description of non-native plant invasions. Plots did not capture fine-scale species distributions across the landscape. Missing patches of invaders limits our ability to quantify spread and the efficacy of control and restoration. Plots might capture spread with invasion of a previously uninvaded subplot (small scale) or another plot (larger scale), but range expansions could be missed given the cost of establishing many plots on a landscape.

Adherence to a stratified-random sample design caused the inventory to miss some non-native species and invaded areas. The combination of the discrete plot and the sample design may have landed a plot next to a non-native patch or individual that would not have been recorded. Furthermore, a priori stratifications must rely on existing data layers with minimum mapping units resulting in unsampled rare and unique sites (Stohlgren et al. 1997a) like rock outcroppings or riparian areas that are often hot spots of invasion but cover too small of an area to appear in many vegetation maps.

\subsection{The art and science of invasive plant species mapping: combining techniques}

A combination of mapping and plot data might be the best way to efficiently understand the composition, distribution, abundance, and impact of invading nonnative plant species on a landscape (Parker et al. 1999). Mapping techniques only tell half the story. While they effectively describe the general distribution of non-native plant species, and, with strategic searching, function as a valuable tool for the early detection of new and rare invaders on the landscape (Stohlgren and Schnase 2006), the metrics may not be repeatable and they ignore native species and important ancillary data needed for predictive spatial models. Plot sampling may miss rare species and fail to capture the fine scale distribution of invasive plant species, but it does describe conditions with accurate and repeatable methods, and records native species information and ancillary data. The two techniques compliment each other. Used together, they increase the environmental gradient sampled, effectively inventory and monitor rare and common non-native plant species on the landscape, and leverage predic- tive capability for early detection and smarter sampling in the future.

One assessment of the usefulness of an inventory method is the evaluation of how well a method covers the environmental variability of the landscape of interest (Stohlgren 2006). It may be that efficient non-native inventory does not need to focus significant effort on areas less likely to be invaded (Table 1), but covering more of the environmental gradient allows for detection of unexpected occurrences caused by range expansions or early invaders. In addition, spatially explicit, repeatable sampling is well suited for use in future monitoring (Stohlgren 2006). The 1999-2004 National Elk Refuge mapping that focused on non-native plant species near roads and rivers left a considerable portion of the environmental landscape unsampled (Table 4, Fig. 5). Despite being limited to 63 sample locations, the 2005 stratified-random plot sampling design improved the coverage of the environmental variability on the Refuge. Mapping in 2005 was designed to cover more of the landscape and was coupled with the plot inventory which forced sampling over an expanded environmental range. Sampling many points in both easily accessible areas and around the randomly distributed points resulted in a large sample size that further improved coverage of the landscape environmental variability. The combination of plot sampling and the coverage of the 2005 mapping effort proved to cover the largest environmental range, suggesting that the combination of the two techniques was the best way to cover landscape environmental variability at the National Elk Refuge.

The detection of non-native species at the National Elk Refuge in the 2005 mapping and plot data exemplifies the synergy of these two methods. Sampling 63 plots in five different vegetation types, we detected 47 non-native plant species (USDA 2005). Mapping at 1,851 locations detected 38 nonnative plant species (USDA 2005). The total number of species detected by each method is similar, but the methods did not capture the same species. Of the nonnative species found in plots, 25 were not detected with mapping techniques, and 16 of the 38 mapped non-native species were not captured with plot sampling. A total of 63 non-native species were captured with the combination of the two methods. Like rare plant surveys, searching with mapping techniques located rare non-native species on the 
landscape. Of the 16 species unique to mapping, 10 species were mapped 10 or fewer times. However, stratified-random plot sampling reached locations and detected rare non-native species that may have otherwise gone unsampled. Of the 25 non-native species unique to plots, eight occurred in only one plot, and another nine non-native species occurred on only two plots (Table 3 ).

The methodological synergy applies at the landscape scale as well. The time involved to catalogue both rare and common non-native plant species means that the entirety of a landscape cannot be realistically inventoried and only specific spots should be selected for monitoring (Stohlgren et al. 1997b). The development of models from the mapping (Fig. 2) was limited by presence-only data, and the plot-based predictive model (Fig. 3) was limited by sample size. While more plots would increase the accuracy of the models, we increased the sample size of a single species distribution model of whitetop by combining the mapping and plot data (Fig. 4). Further sampling or control work of whitetop might be pursued at locations estimated to have a high probability of occurrence. Further inventory work that encounters whitetop on the landscape can be immediately incorporated into this model to adjust the relationship to the dependent variables and improve the quality of the model.

\section{Conclusions}

Divergent designs and methods give mapping and plot-based inventory systems different strengths, and make their information complementary. Forced to random locations by sample design, plots quantified frequency and cover while mapping quantified the surrounding fine-scale distributions. Alternatively, searching and mapping the landscape leveraged the knowledge of local experts and allowed inventory of unique locations where mapping information was augmented by subjectively placed plots. Combining the two methods allows a local weed expert to map non-native plants in locations where they know and expect species to exist, while forcing them to map and record invasive species in and around plots is the combination of an art and a science.

We applaud the efforts to map invasive plant species, but with this study we emphasize the need to augment mapping information with plot data to efficiently improve our understanding of non-native species distributions and our ability to accurately assess range expansions and management effects across landscapes and over time. When used together, the complimentary methods provide a thorough description of the landscape and the distribution of species, more comparable data, and better predictive models. Some of the methods and benefits include:

1. The circular plot used captures repeatable measures of cover, species composition, and species richness and is directly comparable to data collected on a grid across the entire country as part of the National Forest Service, Forest Inventory and Analysis program.

2. The plot data can be used to create spatial models that predict non-native plant species richness, cover of multiple species, and the cover and probability of occurrence of single non-native plant species across the landscape. While these models can be created using simple statistical techniques, accuracy and utility are improved with spatial statistics and remote sensing data.

3. Predictive models can direct early detection and control, and guide smart sampling. Iterative evaluation of data collected on the landscape with these spatial modeling tools can direct further sampling to those areas that are vulnerable to invasion, highly invaded, and undersampled regions of the landscape (Stohlgren and Schnase 2006).

Acknowledgements This work was supported by funding from the National Wildlife Refuge System. We would like to thank Michael Lusk, Eric Cole, Barry Reisweig, and Matt Sprenger for providing access, assistance, and information about the Refuges. Don Carpenter, Ian Roblee-Hertzmark, Rick Shory, Nate Alley, Juliane Zimmerman, and the Greater Yellowstone Coordinating Committee contributed field data. To all we are grateful.

\section{References}

Adler, P. B., \& Lauenroth, W. K. (2003). The power of time: Spatiotemporal scaling of species diversity. Ecology Letters, 6, 749-756.

Barnett, D. T., \& Stohlgren, T. J. (2003). A nested-intensity design for surveying plant diversity. Biodiversity and Conservation, 12(2), 255-278. 
Blossey, B. (1999). Before, during and after: The need for longterm monitoring in invasive plant species management. Biological Invasions, 1, 301-311.

Brown, R. L., \& Peet, R. K. (2003). Diversity and invasibility of southern Appalachian plant communities. Ecology, 84 (1), 32-39.

Burke, M. J., \& Grime, J. P. (1996). An experimental study of plant community invasibility. Ecology, 77(3), 776-790.

Cambell, J. B. (2002). Introduction to remote sensing. New York, NY: Gilford.

Carpenter, A. T., Murray, T. A., \& Buxbaum, J. (2002). Inventorying and mapping invasive plants. Natural Areas Journal, 22(2), 163.

Chong, G. W., Otsuki, Y., Stohlgren, T. J., Guenther, D., Evangelista, P., Villa, C. et al. (2006). Evaluating plant invasions from both habitat and species perspectives. Western North American Naturalist, 66(1), 92-105.

Cleland, E. E., Smith, M. D., Andelman, C. H., Bowles, C., Carney, K. M., Horner-Devine, M. C. et al. (2004). Invasion in space and time: Non-native species richness and relative abundance respond to interannual variation in productivity and diversity. Ecology Letters, 7, 947-957.

Cole, D. N., \& Landres, P. B. (1996). Threats to wilderness ecosystems: Impacts and research needs. Ecological Applications, 6(1), 168-184.

D’Antonio, C. M., Dudley, T. L., \& Mack, M. (1999). Disturbance and biological invasions: Direct effects and feedbacks. In L. R. Walker, (Ed.), Ecosystems of disturbed ground (pp. 413-452). New York, NY: Elsevier.

D’Antonio, C. M., \& Vitousek, P. M. (1992). Biological invasions by exotic grasses, the grass fire cycle, and global change. Annual Review of Ecology and Systematics, 23, 63-87.

De'ath, G., \& Fabricius, K. E. (2000). Classification and regression trees: A powerful yet simple technique for ecological data analysis. Ecology, 81(11), 3178-3192.

DeFerrari, C. M., \& Naiman, R. J. (1994). A multi-scale assessment of the occurrence of exotic plants on the Olympic Peninsula, Washington. Journal of Vegetation Science, 5, 247-258.

DiPietro, D., Kelly, M., Schoenig, S., Johnson, D., \& Yacoub, R. (2002). Califonia weed mapping handbook. California Department of Food and Agriculture. http://www.cain.nbii. org/weedhandbook (October 4, 2005).

Elton, C. (1958). The ecology of invasions by animals and plants. London: Methuen.

FICMNEW (2003). A national early detection and rapid response system for invasive plants in the United States (24 pp.). Washington, DC, http://www.invasivespecies. gov/ (March 3, 2005).

Frayer, W. E., \& Furnival, G. M. (1999). Forest survey sampling designs: A history. Journal of Forestry, 97(12), 4-10.

Freemont County (2006). Freemont County weed and pest mapping. http://www.fcwp.org/Mapping/Mapping.htm (September 15, 2006).

Gelbard, J. L., \& Belnap, J. (2003). Roads as conduits for exotic plant invasions in a semiarid landscape. Conservation Biology, 17(2), 420-432.

Godefroid, S., \& Koedam, N. (2003). Identifying indicator plant species of habitat quality and invasibility as a guide for peri-urban forest management. Biodiversity and Conservation, 12, 1699-1713.
Greater Yellowstone Coordinating Committee (2006) GYA Invasive Species Working Group. http:/www.bsi.montana. edu/web/gycc/subcommittees (September 15, 2006).

Hastings, A., Cuddington, K., Davies, K. F., Dugaw, C. J., Elmendorf, S., Freestone, A. et al. (2005). The spatial spread of invasions: New developments in theory and evidence. Ecology Letters, 8, 91-101.

Hiebert, R. D. (1997). Prioritizing invasive plants and planning for management. In J. O. Luken \& J. W. Thieret (Eds.), Assessment and management of plant invasions. Berlin Heidelberg New York: Springer.

Hiebert, R. (2000). National park service. In: Western rangeland noxious weeds-collecting, sharing and using information, proceeding of a workshop, September 6-7, 2000, Phoenix, AZ. Silver Spring, MD: Charles Valentine Riley Memorial Foundation. http://www.invasivespecies.gov/ other.range.pdf (March 4, 2005).

Higgins, S. I., Richardson, D. M., Cowling, R. M., \& TrinderSmith, T. H. (1999). Predicting the landscape-scale distribution of alien plants and their threat to plant diversity. Conservation Biology, 13(2), 303-313.

Hobbs, R. J., \& Humphries, S. E. (1995). An integrated approach to the ecology and management of plant invasions. Conservation Biology, 9(4), 761-770.

Hulme, P. E. (2003). Biological invasions: Winning the science battles but loosing the conservation war? Oryx, 37(2), 178-193.

Kaiser, J. (1999). Stemming the tide of invasive species. Science, 285, 1836-1841.

Keeley, J. E., Lubin, D., \& Fotheringham, C. J. (2003). Fire and grazing impacts on plant diversity and alien plant invasions in the southern Sierra Nevada. Ecological Applications, 13(5), 1355-1374.

Kennedy, T. A., Naeem, S., Howe, K. M., Knops, J. M. H., Tilman, D., \& Reich, P. (2002). Biodiversity as a barrier to ecological invasion. Nature, 417(6889), 636-638.

Lo, C. P., \& Watson, L. J. (1998). The influence of geographic sampling methods on vegetation map accuracy evaluation in a swampy environment. Photogrammetric Engineering and Remote Sensing, 64(12), 1189-1200.

Mack, R. N., Simberloff, D., Lonsdale, W. M., Evans, H., Clout, M., \& Bazzaz, F. (2000). Biotic invasions: Causes, epidemiology, global consequences and control. Issues in Ecology, 5, 1-19.

McCullagh, P., \& Nelder, J. A. (1989). Generalized linear models (2nd ed.). New York, NY: Chapman \& Hall.

McIntyre, S., \& Lavorel, S. (1994). Predicting richness of native, rare, and exotic plants in response to habitat disturbance across a vegetated landscape. Conservation Biology, 8(2), 521-531.

Menges, E. S. (1996). Three levels of monitoring intensity for rare plant species. Natural Areas Journal, 16(3), 227-237.

Milton, S. J., \& Dean, W. R. J. (1998). Alien plant assemblages near roads in arid and semi-arid South Africa. Diversity and Distributions, 4, 175-187.

Mojave Weed Management Area (2006). Saharan Mustard Mapping Project. http://www.mojavewma.org/projects. php (September 15, 2006).

National Invasive Species Council (2003). General guidelines for the establishment and evaluation of invasive species 
early detection and rapid response systems. Version 1 (16 pp.). http://www.invasivespeciesinfo.gov/council/ GuidelineCommunication.doc (October 4, 2005).

North American Weed Mapping Association (2002). North American invasive plant mapping standards. http://www. nawma.org/documents/Mapping\%20Standards/Invasive $\%$ 20Plant\%20Mapping\%20Standards.pdf (October 4, 2005).

Olivarez, J., \& Beard, R. (2000). The forest service perspective. In: Western rangeland noxious weeds-collecting, sharing and using information, proceeding of a workshop. September 6-7, 2000, Phoenix, AZ. Silver Spring, MD: Charles Valentine Riley Memorial Foundation. http:// www.invasivespecies.gov/other.range.pdf (March 4, 2005).

Parendes, L. A., \& Jones, J. A. (2000). Role of light availability and dispersal in exotic plant invasion along roads and streams in the H. J. Andrews Experimental Forest, Oregon. Conservation Biology, 14(1), 64-75.

Parker, I. M., Simberloff, D., Lonsdale, W. M., Goodell, K., Wonham, P. M., Kareiva, M. H. et al. (1999). Impact: Toward a framework for understanding the ecological effects of invaders. Biological Invasions, 1, 3-19.

Pierson, E. A., \& Mack, R. N. (1990). The population biology of Bromus tectorum in forests: Effect of disturbance, grazing, and litter on seedling establishment and reproduction. Oecologia, 84, 526-533.

Pimentel, D., Lach, L., Zuniga, R., \& Morrison, D. (2000). Environmental and economic costs of nonindigenous species in the United States. BioScience, 50(1), 53-65.

Pimentel, D., Zuniga, R., \& Monison, D. (2005). Update on the environmental and economic costs associated with alieninvasive species in the United States. Ecological Economics, 52(3), 273-288.

Planty-Tabacchi, A.-M., Tabacchi, E., Naiman, R. J., DeFerrari, C., \& Decamps, H. (1996). Invasibility of species-rich communities in riparian zones. Conservation Biology, 10 (2), 598-607.

Randall, J. M. (1996). Weed control and the preservation of biological diversity. Weed Technology, 10(2), 370-383.

Reich, R. M., \& Davis, R. A. (1998). On-line spatial library for the S-Plus statistical software package. Colorado State University, Fort Collins, CO, http://www.warnercnr. colostate.edu/ robin/ (October 5, 2005).

Reich, R. M., Lundquist, J. E., \& Bravo, V. A. (2004). Spatial models for estimating fuel loads in the Black Hills, South Dakota, USA. International Journal of Wildland Fire, 13, 119-129.

Reuwsaat, T., Ramos, G., \& Jewell, K. (2000). Bureau of land management. In: Western rangeland noxious weeds-collecting, sharing and using information, proceeding of a workshop. September 6-7, 2000, Phoenix, AZ. Silver Spring, MD: Charles Valentine Riley Memorial Foundation. http://www.invasivespecies.gov/other.range.pdf (March 4, 2005).

Roberts, E., Cooksey, D., \& Sheley, R. L. (1999). Montana noxious weed survey and mapping system weed mapping handbook. Montana State University, Bozeman, MT. http://www.montana.edu/places/mtweeds/pubs.html (October 4, 2005).
Salt Lake County (2006). Weed control, mapping. http://www. weeds.slco.org/html/edMap_mapping.html (September 15, 2006).

Sax, D. F. (2002). Native and naturalized plant diversity are positively correlated in scrub communities of California and Chile. Diversity and Distributions, 8(4), 193-210.

Sax, D. F., \& Brown, J. H. (2000). The paradox of invasion. Global Ecology and Biogeography, 9, 363-371.

Schemske, D. W. (1994). Evaluating approaches to conservation of rare and endangered plants. Ecology, 75(3), 584606.

Schnase, J. L., Stohlgren, T. J., \& Smith, J. A. (2002). The National Invasive Species Forecasting System: A strategic NASA/USGS partnership to manage biological invasions. Earth Observing Magazine, 46-49.

Simberloff, D. (2003). How much information on population biology is needed to manage introduced species? Conservation Biology, 17(1), 83-92.

State of Colorado Department of Agriculture (2005). Colorado Weed Mapping Program. http://www.ag.state.co.us/CSD/ Weeds/mapping/CWMProgram.html (October 5, 2005).

Statistical Sciences (2005). S-PLUS 7.0 for Windows. Insightful Corporation.

Stohlgren, T. J. (2006). Measuring plant diversity; lessons from the field. New York, NY: Oxford University Press.

Stohlgren, T. J., Binkley, D., Chong, G. W., Kalkhan, M. A., Schell, L. D., Bull, K. A. et al. (1999). Exotic plant species invade hot spots of native plant diversity. Ecological Monographs, 69(1), 25-46.

Stohlgren, T. J., Bull, K. A., Otsuki, Y., Villa, C. A., \& Lee, M. (1998). Riparian zones as havens for exotic plant species in the central grasslands. Plant Ecology, 138(1), 113-125.

Stohlgren, T. J., Chong, G. W., Kalkhan, M. A., \& Schell, L. D. (1997a). Multiscale sampling of plant diversity: Effects of minimum mapping unit size. Ecological Applications, 7 (3), 1064-1074.

Stohlgren, T. J., Chong, G. W., Kalkhan, M. A., \& Schell, L. D. (1997b). Rapid assessment of plant diversity patterns: A methodology for landscapes. Environmental Monitoring and Assessment, 48(1), 25-43.

Stohlgren, T. J., Chong, G. W., Schell, L. D., Rimar, K. A., Otsuki, Y., Lee, M. et al. (2002). Assessing vulnerability to invasion by nonnative plant species at multiple spatial scales. Environmental Management, 29, 566-577.

Stohlgren, T. J., Coughenour, M. B., Chong, G. W., Binkley, D., Kalkhan, M. A., Schell, L. D. et al. (1997c). Landscape analysis of plant diversity. Landscape Ecology, 12(3), 155-170.

Stohlgren, T. J., Falkner, M. B., \& Schell, L. D. (1995). A modified-whittaker nested vegetation sampling method. Vegetatio, 117(2), 113-121.

Stohlgren, T. J., \& Schnase, J. L. (2006). Risk analysis for biological hazards: What we need to know about invasive species. Risk Analysis, 26(1), 163-173.

Tilman, D. (1999). The ecological consequences of changes in biodiversity: a search for general principles. Ecology, 80 (5), 1455-1475.

Underwood, E. C., Klinger, R., \& Moore, P. E. (2004). Predicting patterns of non-native plant invasions in 
Yosemite National Park, California, USA. Diversity and Distributions, 10(5-6), 447-459.

USDA (2005). The PLANTS Database. version 3.5. USDA, NRCS. Data compiled from various sources by Mark W. Skinner, National Plant Data Center, Baton Rouge, LA 70874-4490 USA. http://www.plants.usda.gov (October 4, 2005).

Vitousek, P. M., Walker, L. R., Whiteaker, L. D., MuellerDombois, D., \& Matson, P. A. (1987). Biological invasion by Myrica faya alters ecosystem development in Hawaii. Science, 238, 802-804.
Westbrooks, R. (1998). Invasive plants, changing the landscape of America: Fact book. Washington, DC: Federal Interagency Committee for the Management of Noxious and Exotic Weeds (FICNMEW).

Wilcove, D. S., Rothstein, D., Dubow, J., Phillips, A., \& Losos, E. (1998). Quantifying threats to imperiled species in the United States. BioScience, 48(8), 607-615.

Wyoming Department of Agriculture (2006). Technical services. http://www.wyagric.state.wy.us/techserv/seedlab/ weeds.htm (September 15, 2006). 